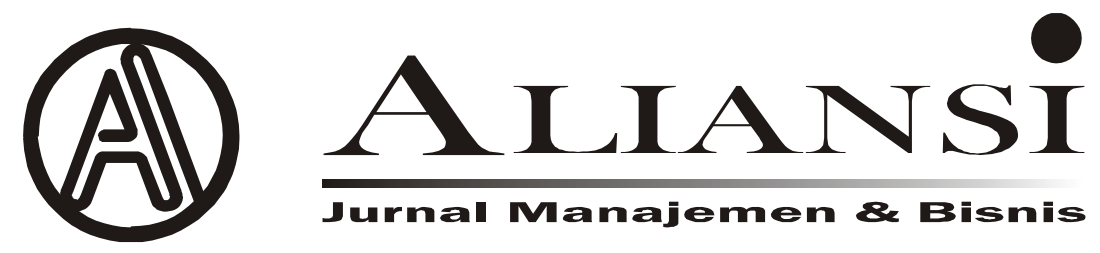

\title{
PENGARUH LABEL HALAL, CITRA MEREK DAN LABEL HARGA TERHADAP KEPUTUSAN PEMBELIAN SUSU FORMULA SGM
}

\author{
Oleh : Yohanes Ferry Cahaya ${ }^{1}$ dan Siti Soimaturrohmah ${ }^{2}$ \\ email : ferry@perbanas.id; siti.soimaturrohmah@yahoo.com
}

\begin{abstract}
This study aims to analyse the effect of label "Halal", brand image and price tag on purchasing decisions of SGM formula milk. The data collection technique in this study used primary data obtained from distributing questionnaires to people who already had children in the Bogor district. The data collected were 100 respondents. The analysis used in this study is a correlation test, multiple linear regression, coefficient of determination and hypothesis testing and is supported by the IBM SPSS Statistic Version 25. The results of this study indicate that (1) label "Halal" has a negative and insignificant effect on purchasing decisions of SGM formula milk and has the least effect, (2) Brand image has a positive and significant effect on purchasing decisions of SGM formula milk and has a greater influence than labels "Halal", (3) the price tag has a positive and significant effect on purchasing decisions of SGM formula milk and has the highest influence. The F test shows if the regression model is considered feasible to predict the independent variable on the dependent variable. The R test shows that the independent variable is able to explain the dependent variable of purchasing decisions by $47.7 \%$.

Keywords: Halal Label, Brand Image, Price Tag, Purchase Decision
\end{abstract}

\section{PENDAHULUAN}

Indonesia merupakan negara yang mempunyai angka kelahiran yang tinggi. Sesuai data yang diinfokan dari UNICEF “United Nations Emergency Children's Fund" ada sekitar 13.020 bayi lahir di awal tahun 2020. Indonesia salah satu negara penyumbang kelahiran yaitu sekitar 3,32 persen dari jumlah total 392.078 bayi di awal tahun 2020. Jumlah kelahiran di Indonesia merupakan yang paling tinggi di dunia, hal ini mengakibatkan indonesia berada pada peringkat ke lima setelah India, Cina, Nigeria, dan Pakistan (www.unicef.org). Pada kondisi pandemic saat ini dengan tinggat kelahiran yang tinggi menimbulkan suatu fenomena lonjakan angka kelahiran penduduk (baby boom) sejak covid-19 berstatus pandemic pada bulan maret lalu. India menduduki peringkat pertama dan sekaligus adalah yang paling besar yaitu hingga 20,1 juta kelahiran kemudian peringkat kedua adalah Tiongkok (13,5 juta kelahiran), Peringkat ketiga adalah Nigeria (6,4 juta kelahiran), peringkat keempat yaitu negara Pakistan (5 juta kelahiran), kemudian disusul Indonesia sekaligus sebagai peringkat kelima (4juta kelahiran. (databoks.katadata.co.id). Jumlah angka kelahiran bayi di Indonesia adalah termasuk tinggi. Hal ini menjadi pasar yang sangat menguntungkan untuk perusahaan penghasil produk kebutuhan bayi misalnya adalah produk susu formula. Salah satu produsen untuk susu formula yang cukup terkenal antara lain Sarihusada Generasi Mahardika (Danone Group). Dari data yang didapat, perusahaan tersebut mampu menguasai pasar susu formula sebesar 24,6\% di tahun 2019 dan menempati urutan kedua setelah Dancow dengan pangsa pasar sebesar 24,9, sementara rekan satu perusahaan dengan sarihusada generasi mahardika yaitu bebelac dengan $23,3 \%$, Lactogen dengan 7,0\% dan, Susu bendera 5,1\%. (www.topbrand-award.com).

Indonesia memiliki kapasitas pasar yang besar untuk industri halal dunia, berdasarkan laporan yang diterbitkan oleh Thomson Reuters dalam State of The Global Islamic Economy 2016/2017 menempatkan Indonesia pada peringkat pertama dalam hal konsumsi makanan halal sebesar \$154,9 miliar (Mahendra 2020). Konsumen ketika membeli makanan halal juga akan dipengaruhi oleh bagaimana pemahaman mereka tentang agama Islam yang mengarah pada kesadaran mereka untuk hanya mengkonsumsi makanan halal (Mahendra 2020). Label Halal penting untuk produk impor yang 
dikonsumsi oleh masyarakat Indonesia yang mayoritas beragama Islam (Simbolon 2019). Decision making by consumers to purchase a product begins with an awareness of the fulfillment of needs and desires (Purwanto et al., 2021). Muslim consumers are faced with a broad selection of Halal products and services. Islam adalah agama yang komprehensif yang mencakup semua aspek kehidupan. Islam berusaha memberikan tuntunan menuju apa yang baik dan bermanfaat bagi manusia dengan konsep "Halal". Halal secara sederhana berarti diperbolehkan dan halal. Lawan dari Halal adalah "haram" yang berarti suatu perbuatan atau hal yang dilarang oleh Tuhan Yang Maha Esa (Muneeza, 2021)

Each product group offers many different local and internationally recognized brands. These brands (hereinafter referred to as Halal brand) use Halal logos or/and symbols that provide assurance to the consumers particularly the Muslims that the ingredients used and the production processes are according to Islamic Shariah (Ali et al, 2019). (Khresna, 2020) Sertifikat halal yaitu suatu aturan yang dibuat oleh institusi MUI untuk menyatakan halal atau tidaknya suatu produk sesuai dengan pedoman syariat islam sehingga bertujuan dengan kepastian hukum bagi yang mengkonsumsinya. Peraturan yang terkait dengan halalnya suatu produk tertulis pada Peraturan Pemerintah No. 69 Tahun 1999 pasal 2 ayat 1 yaitu tentang label atau kemasan suatu produk, bahwa setiap orang/perusahaan yang memproduksi suatu produk atau memasarkan pangan yang dikemas dalam wilayah Indonesia untuk diperdagangkan wajib mencantumkan label didalam atau di kemasan pangan. Penelitian terdahulu yang sudah dilakukan oleh (andriansyah et.al 2020) menyebutkan bahwa variable label halal berpengaruh positif terhadap keputusan pembelian. Produk halal adalah sebuah simbol kebersihan, keamanan dan standar kualitas bagi konsumen Muslim. Sehingga brand awareness halal dapat menjadi sebuah faktor yang mempengaruhi perilaku konsumen dalam membeli produk atau jasa (Wardani et.al, 2020) Halal Brand Image didefinisikan sebagai persepsi merek yang tercermin dalam asosiasi merek halal yang ada dalam ingatan pelanggan. Namun, citra merek Islam dipandang berbeda oleh orang yang berbeda di tempat yang berbeda bahkan dari pelanggan Muslim (Wardani et.al, 2020). Keputusan akhir untuk membeli produk berdasarkan label makanan sangat bervariasi berdasarkan jenis kelamin, usia, kebiasaan makan, dan lokasi tempat tinggal konsumen (Kumar et.al 2017)

\section{TINJAUAN PUSTAKA}

Nurmadina (2016) mengenai Analisis FaktorFaktor yang Mempengaruhi Keputusan Pembelian Secara Online. Penelitian ini merupakan jenis penelitian kuantitatif dengan teknik analisis data asumsi klasik. Berdasarkan hasil penelitian menunjukkan bahwa variabel harga berpengaruh signifikan terhadap keputusan pembelian online.

Muhammad Fiqhur Rizali (2019) mengenai Analisis Faktor-Faktor yang Mempengaruhi Keputusan Pembelian Konsumen di Sakinah 212 Mart Kediri. Penelitian ini merupakan jenis penelitian kuantitatif jenis asosiatif dengan teknik analisis faktor dan analisis regresi berganda. Berdasarkan hasil penelitian menunjukkan adanya pengaruh yang positif dan signifikan variabel harga terhadap keputusan pembelian.

Heryanto Hotnauli Sihombing (2017) mengenai Pengaruh Kualitas Produk, Harga dan Iklan Terhadap Keputusan Pembelian CFC. Penelitian ini merupakan metode penelitian deskriptif kuantitatif dangan menggunakan analisis regresi linear berganda. Berdasarkan hasil penelitian menunjukkan bahwa harga tidak berpengaruh secara signifikan terhadap keputusan pembelian CFC.

Dian Puspitarini (2013) mengenai Pengaruh Faktor Kebudayaan, Sosial, Pribadi dan Psikologi Terhadap Proses Keputusan Pembelian Produk Pizza Hut Cabang Jl. Jendral Sudirman No.53 Yogyakarta. Penelitian ini merupakan metode kuantitatif dengan analisis regresi berganda. Berdasarkan hasil penelitian menunjukkan bahwa variabel sosial berpengaruh positif dan signifikan terhadap keputusan pembelian.

\section{METODOLOGI PENELITIAN}

Penelitian ini adalah penelitian kuantitatif dengan pendenakatn deskriptif. Populasi dalam penelitian ini adalah seluruh pelanggan/konsumen susu formula SGM di wilayah kab. Bogor tidak diketahui secara pasti oleh peneliti. Penetapan jumlah sampel pada penelitian ini dilakukan berdasarkan ketentuan (Ferdinand, 2011), yaitu untuk penelitian multivariate, besarnya sampel dapat ditentukan sebanyak 25 kali variabel independen/bebas. Berhubung variable bebas pada penelitian ini ada 3 (tiga), maka jumlah sampel 
pada penelitian ini paling sedikit sebanyak 100 orang. Cara memperoleh sampel penelitian ini menggunakan teknik aksidental (convenience sampling), yaitu mendapatkan sampel berdasarkan siapa saja yang secara kebetulan bertemu dengan peneliti selama waktu penyebaran kuesioner penelitian. Sampel akan diambil menggunakan kuesioner yang terdiri dari 28 pertanyaan dari semua variabel.

\section{Pengaruh Label Halal Terhadap Keputusan} Pembelian

Penelitian yang sudah dilakuan oleh (Afzaal et.al, 2020) bahwa Halal berpengaruh positif terhadap keputusan pembelian. Sedangkan penelitian yang dilakukan oleh (Khresna et.al 2020; Henry 2017; Mahendra 2020 ) menunjukan bahwa labelisasi halal berpengaruh positif terhadap keputusan pembelian.

H1: label halal berpengaruh positif terhadap keputusan pembelian

\section{Pengaruh Citra Merek Terhadap Keputusan Pembelian}

Citra merek berkorelasi positif dengan keputusan membeli dan niat membeli kembali (Bhakuni et al., 2021; Hammam et.al, 2021). (Wardani et.al, 2020) menyimpulkan bahwa Citra merek berpengaruh positif dan signifikan terhadap keputusan pembelian produk safi scincare. Sedangkan menurut (Juhara, 2020) bahwa citra merek berpengaruh positif terhadap keputusan pembelian.

$\mathrm{H} 2$ : brand (citra merek) produk berpengaruh positif terhadap keputusan pembelian

Pengaruh Harga Terhadap Keputusan Pembelian

Harga dan suasana toko memiliki pengaruh yang signifikan terhadap keputusan pembelian di ritel syariah (Monoarfa et.al, 2021). Harga memainkan peran penting dalam keputusan pembelian (Arora et.al 2021). (Wardani et.al, 2020) bahwa variabel harga secara positif memiliki pengaruh signifikan terhadap variabel keputusan pembelian. Sedangkan menurut (Khresna et.al, 2020) bahwa harga berpengaruh positif terhadap keputusan.

H3: harga berpengaruh positif terhadap keputusan pembelian produk SGM

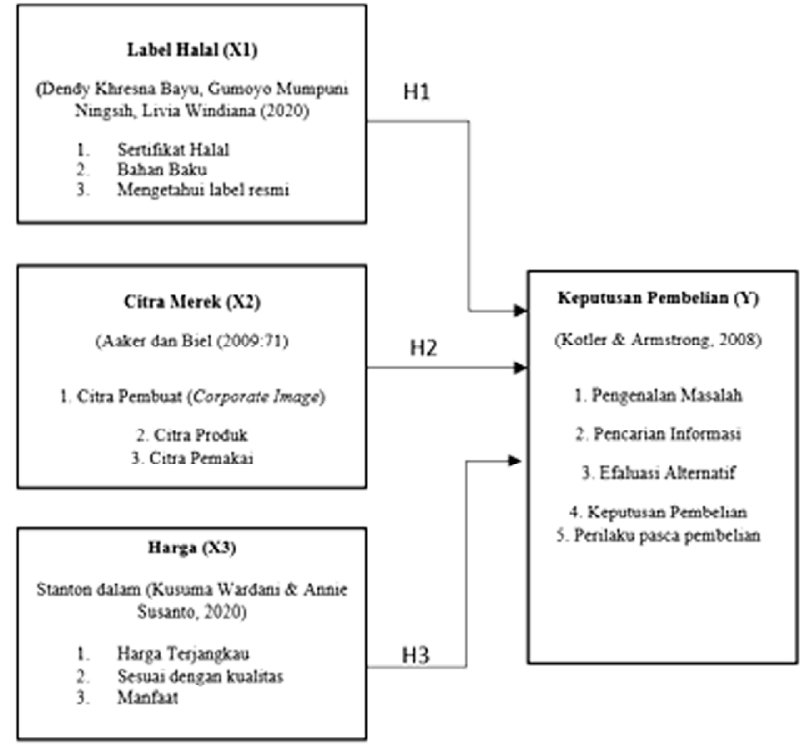

\section{Populasi dan Sampel Penelitian}

Populasi adalah seluruh kelompok dari orang, kejadian, atau sesuatu yang menjadi perhatian daripada investigasi dari peneliti (Sekaran et al, 2016). Teknik penentuan target populasi yang diterapkan dalam penelitian ini berpedoman pada penelitianpenelitian terdahulu. Pada penelitian ini, populasi yang digunakan adalah pelanggan/konsumen susu formula SGM di wilayah kab. Bogor

Menurut Showkat \& Parven (2017), Teknik pengambilan sampel dapat dibagi menjadi dua jenis yaitu probability sampling dan nonprobability sampling. Teknik pengambilan sampel pada penelitian ini menggunakan nonprobability sampling, yaitu teknik pengambilan sampel yang tidak memberikan peluang / kesempatan yang sama bagi setiap unsur atau anggota populasi untuk dipilih menjadi sampel. (Sugiyono, 2011). Merujuk pada Hair et al (2014) menemukan bahwa ukuran sampel yang sesuai adalah 100 sampai 200. Dalam penelitian ini, jumlah indikator penelitian sebanyak 20 sehingga jumlah sampel minimum adalah 5 kali jumlah indikator yang diestimasi atau sebanyak $5 \times 20=100$ Jumlah sampel yang digunakan lebih banyak yaitu sebesar 100

\section{Teknik Pengumpulan Data}

Pengumpulan data dilakukan dengan teknik aksidental (convenience sampling), yaitu mendapatkan sampel berdasarkan siapa saja yang secara kebetulan bertemu dengan peneliti selama waktu penyebaran kuesioner penelitian 


\section{Teknik Analisis Data}

Analisis yang digunakan dalam penelitian diawali dengan ini uji validitas, uji realibilitas, uji asumsi klasik (uji normalitas, uji multikoliniearitas, uji Heterokeastisitas), uji auto korelasi, uji regresi linier berganda, uji F, uji tan uji R

\section{HASIL DAN PEMBAHASAN}

Hasil uji validitas menyatakan bahwa semua varibel dinyatakan valid. Hasil uji realibilitas menyatakan bahwa semua variabel reliabel. Hasil uji normalitas dapat disimpulkan bahwa residual berdistribusi normal. Hasil uji heteroskedastisitas menyatakan terdapat residual menyebar secara acak dan tidak membentuk pola teratur, sehingga dapat disimpulkan bahwa variabel bebas tidak mengalami heteroskedastisitas sehingga layak digunakan dalam penelitian ini. Hasil data pengolahan data dari uji multikolinearitas disimpulkan bahwa untuk ketiga variabel independen memiliki $\mathrm{VIF}<10$, dimana masing masing variabel seperti label halal memiliki nilai VIF 2.070, citra merek memiliki VIF 2.887, dan label harga memiliki VIF 1.947. Jadi kesimpulannya adalah model regresi tersebut tidak menunjukan adanya masalah multikolinearitas sehingga asumsi terpenuhi pada penelitian ini. Uji autokorelasi berdasarkan data SPSS diperoleh nilai Durbin Watson $(\mathrm{d})=2.169$ table D-W dengan $\mathrm{n}=100$ dan $\mathrm{k}$ (jumlah variabel independen $)=$ 3 adalah $\mathrm{dL}=1.6131$ dan $\mathrm{dU}=1.7364,4-\mathrm{dL}=2.3869$, 4- $\mathrm{dU}=2.2636$. Nilai $\mathrm{d}$ berada pada selang $\mathrm{dU}<\mathrm{d}<$ 4 - dU yaitu $1.7364<2.169<2.2636$ sehingga dapat disimpulkan tidak terjadi autokorelasi atau asumsi terpenuhi.

\section{Analisis Koefisien Korelasi}

Tabel 1

Analisis Koefisien Korelasi

Correlations

\begin{tabular}{|c|c|c|c|c|c|}
\hline \multicolumn{6}{|c|}{ Correlations } \\
\hline & & $\begin{array}{l}\text { Label } \\
\text { Halal }\end{array}$ & $\begin{array}{c}\text { Citra } \\
\text { Merek }\end{array}$ & $\begin{array}{l}\text { Label } \\
\text { Harga }\end{array}$ & $\begin{array}{l}\text { Keputusan } \\
\text { Pembelian }\end{array}$ \\
\hline \multirow[t]{3}{*}{ Label Halal } & Pearson Correlation & 1 & .718 & .530 & .478 \\
\hline & \begin{tabular}{|l|} 
Sig. (2-tailed) \\
\end{tabular} & & .000 & .000 & .000 \\
\hline & $\mathrm{N}$ & 100 & 100 & 100 & 100 \\
\hline \multirow[t]{3}{*}{ Citra Merek } & Pearson Correlation & .718 & 1 & .696 & .617 \\
\hline & \begin{tabular}{|l|} 
Sig. (2-tailed) \\
\end{tabular} & .000 & & .000 & .000 \\
\hline & $\mathrm{N}$ & 100 & 100 & 100 & 100 \\
\hline \multirow[t]{3}{*}{ Label Harga } & Pearson Correlation & .530 & .696 & 1 & .669 \\
\hline & \begin{tabular}{|l} 
Sig. (2-tailed) \\
\end{tabular} & .000 & .000 & & .000 \\
\hline & $\mathrm{N}$ & 100 & 100 & 100 & 100 \\
\hline \multirow{3}{*}{$\begin{array}{l}\text { Keputusan } \\
\text { Pembelian }\end{array}$} & Pearson Correlation & .478 & .617 & .669 & 1 \\
\hline & \begin{tabular}{|l|} 
Sig. (2-tailed) \\
\end{tabular} & .000 & .000 & .000 & \\
\hline & $\mathrm{N}$ & 100 & 100 & 100 & 100 \\
\hline
\end{tabular}

Sumber : Data diolah
1. Koefisien korelasi untuk variabel label halal (X1)

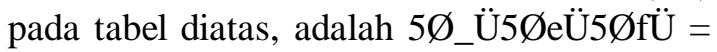
0.478 . Menurut tingkat keeratan antara variabel bebas dengan variabel terikat menunjukkan bahwa terjadi hubungan dengan kategori sedang.

2. Koefisien korelasi untuk variabel Citra Merek (X2) pada tabel diatas, dapat adalah 5Ø_Ü5ØeÜ5Øfய̈ $=0.617$ Menurut tingkat keeratan antara variabel bebas dengan variabel terikat menunjukkan bahwa terjadi hubungan dengan kategori kuat. Sedangkan arah hubungan adalah positif karena nilai $r$ positif, berarti semakin tinggi tingkat citra perusahaan semakin meningkatkan minat sewa.

3. Koefisien korelasi Pearson untuk variabel label harga (X3) dengan variabel minat sewa (Y) adalah 5Ø_Ü5ØeÜ5Øfய̈ $=0.669$. Menurut tingkat keeratan antara variabel bebas dengan variabel terikat menunjukkan bahwa terjadi hubungan dengan kategori kuat

\section{Analisis Regresi Linier Berganda}

Tabel 2

Analisis Regesi Linier Berganda

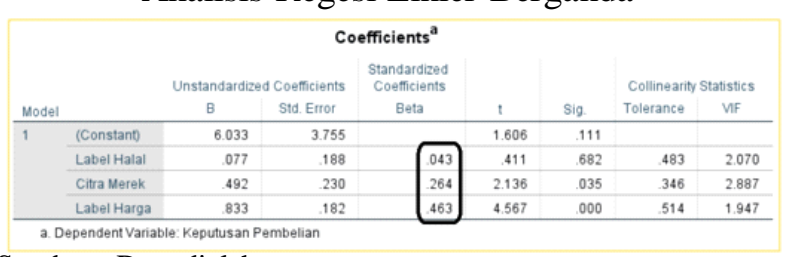

Sumber : Data diolah

- $\quad$ Nilai regresi label halal menunjukan terdapat pengaruh positif terhadap keputusan pembelian dan sekaligus mempunyai pengaruh paling rendah.

- $\quad$ Nilai regresi citra merek menunjukan terdapat pengaruh positif terhadap keputusan pembelian.

- $\quad$ Nilai regresi label harga menunjukan terdapat pengaruh positif terhadap keputusan pembelian dan sekaligus mempunyai nilai yang lebih tinggi.

\section{Uji Signifikansi Parsial (Uji T)}

Tabel 3

Uji Signifikansi Parsial (Uji T)

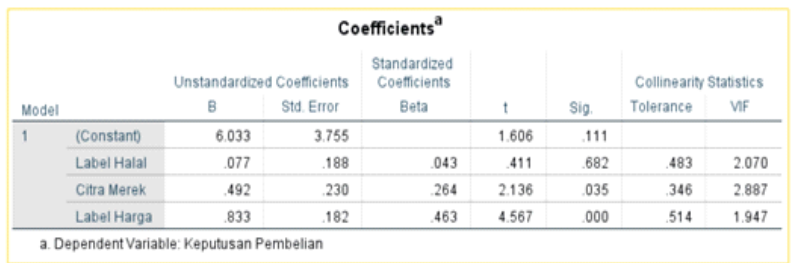

Sumber : Data diolah 
- Hasil uji hipotesis mengenai pengaruh antara variabel label halal (X1) dan keputusan konsumen (Y), menunjukan bahwa nilai t-hitung 0,411<t-tabel 1,98498 maka (H1) ditolak artinya variabel label halal berpengaruh negatif dan tidak signifikan terhadap keputusan pembelian.

- Hasil uji hipotesis mengenai pengaruh antara variabel citra merek (X2) dan keputusan konsumen (Y), menunjukan bahwa nilai t-hitung $2.136>\mathrm{t}$-tabel 1,98498 maka $(\mathrm{H} 2)$ diterima artinya variabel citra merek berpengaruh positif dan signifikan terhadap keputusan pembelian.

- Hasil uji hipotesis mengenai pengaruh antara variabel label harga (X3) dan keputusan konsumen (Y), menunjukan bahwa nilai t-hitung $4.567<\mathrm{t}$-tabel 1,98498 maka $(\mathrm{H} 3)$ diterima artinya variabel label harga berpengaruh positif dan signifikan terhadap keputusan pembelian.

\section{Uji Signifikansi Simultan (Uji F)}

Tabel 4

Uji Signifikansi Simultan (Uji F)

\begin{tabular}{|c|c|c|c|c|c|c|}
\hline \multicolumn{7}{|c|}{ ANOVA $^{a}$} \\
\hline Model & & $\begin{array}{l}\text { Sum of } \\
\text { Squares }\end{array}$ & df & Mean Square & $\mathrm{F}$ & Sig. \\
\hline \multirow[t]{3}{*}{1} & Regression & 2087.324 & 3 & 695.775 & 31.133 & $.000^{b}$ \\
\hline & Residual & 2145.436 & 96 & 22.348 & & \\
\hline & Total & 4232.760 & 99 & & & \\
\hline
\end{tabular}

Sumber : Data diolah

Perhitungan $\mathrm{f}$ tabel pada penelitian ini didapatkan nilai sebesar 2,47 (100-3=97). Nilai f hitung diperoleh sebesar 31.133. Maka dapat diketahui bahwa nilai $\mathrm{f}$ hitung 31.133 lebih besar $>$ dari $\mathrm{f}$ tabel 2,47 dengan tingkat signifikansi 0,000 lebih kecil dari $<0,05$. Hal ini dapat disimpulkan bahwa model regresi tersebut layak untuk meramalkan variabel bebas (label halal, citra merek dan label harga) terhadap variabel (keputusan pembelian).

\section{Uji Koefisien Determinasi (R2)}

Koefisien determinasi bertujuan untuk mengukur seberapa jauh kemampuan model dalam menerangkan variasi variabel terikat. Apabila jumlah variabel bebas yang ditelitilebih dari satu variabel, maka perlu menggunakan R Square Adjusted sebagai ukuran determinasi. Berikut adalah tabel uji koefisien determinasi
Tabel 5

Uii Koefisien Determinasi (R2)

\begin{tabular}{|c|c|c|c|c|}
\hline \multicolumn{5}{|c|}{ Model Summary } \\
\hline Model & $\mathrm{R}$ & R Square & $\begin{array}{l}\text { Adjusted R } \\
\text { Square }\end{array}$ & $\begin{array}{l}\text { Std. Error of } \\
\text { the Estimate }\end{array}$ \\
\hline 1 & $.702^{\mathrm{a}}$ & .493 & .477 & 4.727 \\
\hline \multicolumn{5}{|c|}{$\begin{array}{l}\text { a. Predictors: (Constant), Label Harga, Label Halal, Citra } \\
\text { Merek }\end{array}$} \\
\hline \multicolumn{5}{|c|}{ b. Dependent Variable: Keputusan Pembelian } \\
\hline
\end{tabular}

Sumber : Data diolah

Hasil analisis diatas menunjukan bahwa nilai koefisien determinasi adalah 0,477. Hal ini menjelaskan bahwa $47,7 \%$, variabel keputusan pembelian dapat dijelaskan oleh variabel independen yaitu label halal, citra merek dan label harga, sedangkan sianya $(1-0,477) 0,523$ atau $52,3 \%$ dijelaskan oleh variabel-variabel lain diluar model penelitian.

Hasil penelitian ini apabila dibandingkan dengan hasil penelitian terdahulu, maka akan tampak perbandinga sbb:

Perbandingan Penelitian Terdahulu Dengan Penelitian Yang Dilakukan

\begin{tabular}{|c|c|c|c|}
\hline No & Peneliti & Judul Penelitian & Hasil Penelitian \\
\hline 1 & \begin{tabular}{|l} 
Ali et.al (2021) \\
\end{tabular} & $\begin{array}{l}\text { Investigating the antecedents of } \\
\text { halal brand product purchase } \\
\text { intention: an empirical } \\
\text { investigation }\end{array}$ & $\begin{array}{l}\text { Halal brand image has a direct } \\
\text { positive on Purchase intention }\end{array}$ \\
\hline 2 & Khresna et.al (2020) & $\begin{array}{l}\text { Pengaruh labelisasi halal dan harga } \\
\text { terhadap keputusan pembelian } \\
\text { chatime }\end{array}$ & $\begin{array}{c}\text { Seluruh variable penelitian } \\
\text { produk (X1) dan harga (X3) } \\
\text { berpengaruh positif terhadap } \\
\text { keputusan pembelian (Y), } \\
\text { sedangkan labelisasi Halal }(\mathrm{X} 2) \\
\text { tidak terpengaruh terhadap } \\
\text { keputusan pembelian }(\mathrm{Y})\end{array}$ \\
\hline 3 & \begin{tabular}{|l|l} 
Ali et.al (2018) \\
\end{tabular} & $\begin{array}{l}\text { Antecedents of consumers' Halal } \\
\text { brand purchase intention: } \\
\text { an integrated approach }\end{array}$ & $\begin{array}{l}\text { Halal brand image has a direct } \\
\text { and positive impact on consumer } \\
\text { brand } \\
\text { Purchase intention. }\end{array}$ \\
\hline 4 & $\begin{array}{l}\begin{array}{l}\text { Rachmawati et.al } \\
(2020)\end{array} \\
\end{array}$ & $\begin{array}{l}\text { A moderating role of halal } \\
\text { brand awareness to purchase } \\
\text { decision making }\end{array}$ & $\begin{array}{c}\text { Halal brand awareness } \\
\text { moderates the relationship } \\
\text { between product knowledge and } \\
\text { purchase decision-making. }\end{array}$ \\
\hline 5 & \begin{tabular}{|l|} 
Jaiyeoba et.al (2020) \\
\end{tabular} & \begin{tabular}{|c|} 
Halal certify cation mark, brand \\
quality, and awareness \\
Do they influence buying decisions of \\
Nigerian consumers?
\end{tabular} & $\begin{array}{c}\text { Halal certification mark is } \\
\text { positively related to consumers } \\
\text { decisions to buy halal certified } \\
\text { products. }\end{array}$ \\
\hline 6 & $\begin{array}{l}\begin{array}{l}\text { Genoveva et.al } \\
(2020)\end{array} \\
\end{array}$ & $\begin{array}{c}\text { The Influence of Brand Image, Halal } \\
\text { Label and Halal Awareness on } \\
\text { Customers Purchasing Decision of } \\
\text { Halal Cosmetic }\end{array}$ & $\begin{array}{c}\text { Brand Image and Halal } \\
\text { Awareness have significance on } \\
\text { Purchasing Decision and Halal } \\
\text { Label has no significance on } \\
\text { Purchasing Decision. }\end{array}$ \\
\hline 7 & \begin{tabular}{|l} 
Wibowo et.al (2020) \\
\end{tabular} & $\begin{array}{l}\text { The Determinants of Halal Labeling } \\
\text { and Brand Image Towards Purchase } \\
\text { Intention and Purchasing Decision }\end{array}$ & $\begin{array}{l}\text { Halal labeling had a positive and } \\
\text { significant effect onthe } \\
\text { purchasing decisions, } \\
\text { Brand image positively and } \\
\text { significantly affected thepurchase } \\
\text { intention }\end{array}$ \\
\hline 8 & \begin{tabular}{|l} 
Wardani et.al (2020) \\
\end{tabular} & $\begin{array}{c}\text { The Impact of Brand Image and } \\
\text { Perceived Price on Imported Halal } \\
\text { Skincare Purchase Decision: Study } \\
\text { on Safi's Consumers in Central Java, } \\
\text { Indonesia }\end{array}$ & $\begin{array}{l}\text { brand image and perceived price } \\
\text { has a positive and significant } \\
\text { effect to the purchasing decisions } \\
\text { of Safi skincare products in } \\
\text { Central Java }\end{array}$ \\
\hline 9 & Bashir et.al (2019) & $\begin{array}{c}\text { Effect of Halal awareness, halal logo } \\
\text { and attitude on foreign consumers } \\
\text { purchase intention }\end{array}$ & $\begin{array}{c}\text { Halal logo has a positive on } \\
\text { consumer purchase intention } \\
\text { towards purchasing halal food } \\
\text { product }\end{array}$ \\
\hline 10 & $\begin{array}{l}\text { Purwanto et.al } \\
\text { (2020) }\end{array}$ & $\begin{array}{c}\text { The Role of } \\
\text { Brand Image, Food Safety, } \\
\text { Awareness, } \\
\text { Certification } \\
\text { on Halal Food } \\
\text { Purchase Intention: } \\
\text { An Empirical Study on Indonesian } \\
\text { Consumers }\end{array}$ & $\begin{array}{c}\text { Brand image affects purchase } \\
\text { intention, Halal certificate affects } \\
\text { purchase intention. }\end{array}$ \\
\hline 11 & \begin{tabular}{|l}
$\begin{array}{l}\text { Siti Soimaturrohmah } \\
(2021)\end{array}$ \\
\end{tabular} & $\begin{array}{c}\text { Pengaruh label halal, citra merek dan } \\
\text { label harga terhadap keputusan }\end{array}$ & $\begin{array}{c}\text { Label halal, citra merek, label } \\
\text { harga dan keputusan pembelian }\end{array}$ \\
\hline
\end{tabular}




\section{SIMPULAN}

Berdasarkan hasil penelitian dan pembahasan, maka dapat ditarik beberapa kesimpulan sebagai berikut. Variabel Label Halal berpengaruh negatif dan tidak signifikan terhadap keputusan pembelian dan mempunyai pengaruh paling rendah diantara kedua variabel lainnya, menolak H1. Variabel Citra Merek berpengaruh positif dan signifikan terhadap keputusan pembelian dan mempunyai pengaruh lebih besar daripada label halal, namun lebih kecil daripada label harga, menerima H2. Variabel Label Harga berpengaruh positif dan signifikan terhadap keputusan pembelian (Y) dan mempunyai pengaruh paling tinggi diantara kedua variabel lainnya, menerima H3.

\section{Saran}

Berdasarkan hasil penelitian, pembahasan dan kesimpulan yang diperoleh, maka saran yang dapat diberikan sebagai berikut.

1. Bagi Pengusaha

a) Berkaitan dengan label halal perlu adanya perbesaran logo dari kemasan yang sebelumnya, sehingga konsumen akan lebih bisa membaca label halal tersebut dan yakin untuk mengkonsumsi produk tsb.

b) Berkaitan dengan citra merek perlu adanya insentif atau reward bagi konsumen yang menggunakan produk SGM agar bisa merekomendasikan kepada orang lain yang belum menggunakan produk susu SGM.

c) Terkait dengan label harga agar diperbesar angkanya agar konsumen dapat melihat dengan lebih jelas

2. Bagi Peneliti Selanjutnya

a. Penelitian berikutnya disarankan dapat mengembangkan peneltian ini dengan meneliti faktor lain yang mempengaruhi keputusan pembelian. Seperti, kualitas pelayanan, lokasi, sosial dan lain-lainnya.

b. Penelitian selanjutnya diharapkan menggunakan data yang lebih akurat dengan jumlah yang lebih banyak. Penggunaan data yang lebih akurat memungkinkan hasil yang lebih baik.

\section{DAFTAR PUSTAKA}

Andriansyah, Y., Arifin, R., \& S., A. R. (2016). Pengaruh Label Halal, Citra Merek Dan Kualitas Produk Terhadap Keputusan Pembelian Teh Racek. Jurnal Riset Manajemen, 98-112.
Ali, A., Xiaoling, G., Sherwani, M. and Ali, A. (2018), "Antecedents of consumers' Halal brand purchase intention: an integrated approach", Management Decision, Vol. 56 No. 4, pp. 715-735. https://doi.org/10.1108/MD-112016-0785

Ali, A., Sherwani, M., Ali, A., Ali, Z. and Sherwani, M. (2021), "Investigating the antecedents of halal brand product purchase intention: an empirical investigation", Journal of Islamic Marketing, Vol. 12 No. 7, pp. 1339-1362. https:/ /doi.org/10.1108/JIMA-03-2019-0063

Arora, A., Rani, N., Devi, C. and Gupta, S. (2021), "Factors affecting consumer purchase intentions of organic food through fuzzy AHP", International Journal of Quality \& Reliability Management, Vol. ahead-of-print No. ahead-of-print. https://doi.org/10.1108/ IJQRM-01-2021-0019

Aspan, H., Sipayung, I. M., Muharrami, A. P., \& Ritonga, H. M. (2017). The Effect of Halal Label, Halal Awarness, Product Price, and Brand Image to the Purchasing Decision on Cosmetic Products (Case Study on Consumers of Sari Ayu Martha Tilaar in Binjai City). International Journal of Global Sustainability, 1(1), 55. https://doi.org/10.5296/ ijgs.v1i1.12017

Bashir, A.M. (2019), "Effect of halal awareness, halal logo and attitude on foreign consumers' purchase intention", British Food Journal, Vol. 121 No. 9, pp. 1998-2015. https://doi.org/ 10.1108/BFJ-01-2019-0011

Bhakuni, P., Rajput, S., Sharma, B. K., \& Bhakar, S. S. (2021). Relationship Between Brand Image and Store Image As Drivers of Repurchase Intention in Apparel Stores. Gurukul Business Review, 17(1). https:// doi.org/10.48205/gbr.v17.6

Genoveva, G., \& Utami, N. N. (2020). the Influence of Brand Image, Halal Label, and Halal Awareness on Customers Purchasing Decision of Halal Cosmetic. Jurnal Muara Ilmu Ekonomi Dan Bisnis, 4(2), 355. https://doi.org/ 10.24912/jmieb.v4i2.8381

Hammam, S. A., \& Emil Robert, K. (2021). The effect of user experience, brand image, and trust on purchase decision in social commerce facebook. Journal of Theoretical and Applied Information Technology, 99(19), 4557-4568. 
Jaiyeoba, H.B., Abdullah, M.A. and Dzuljastri, A.R. (2020), "Halal certification mark, brand quality, and awareness: Do they influence buying decisions of Nigerian consumers?", Journal of Islamic Marketing, Vol. 11 No. 6, pp. 16571670. https://doi.org/10.1108/JIMA-07-2019$\underline{0155}$

Juhara, S. W. el. (2020). The Determinants of Halal Labeling and Brand Image Towards Purchase Intention and Purchasing Decision. Conference: 4th International Conference on Sustainable Innovation 2020-Accounting and Management (ICOSIAMS 2020).

Khresna Bayu, D., Mumpuni Ningsih, G. . and Windiana, L. . (2020) "Pengaruh Labelisasi Halal, Merek Dan Harga Terhadap Keputusan Pembelian Minuman CHATIME", Jurnal Sosial Ekonomi Pertanian, 16(3), pp. 239 256. doi: 10.20956/jsep.v16i3.12403.

Kumar, N. and Kapoor, S. (2017), "Do labels influence purchase decisions of food products? Study of young consumers of an emerging market", British Food Journal, Vol. 119 No. 2, pp. 218-229. https://doi.org/10.1108/BFJ-062016-0249

Mahendra, W. (2020). The Influence of Religiusity and Halal Label through Halal Awareness Purchase Decisions. Budapest International Research and Critics Institute-Journal (BIRCI-Journal), 1739-1746.

Muneeza, A. (2021). Halal certi fi cation process for fi sheries products in Maldives. 12(2), 451-466. https://doi.org/10.1108/JIMA-022019-0035

Purwanto, A., Haque, M. G., Sunarsih, D., \& Asbari, M. (2021). The Role of Brand Image, Food Safety, Awareness, Certification on Halal Food Purchase Intention: An Empirical Study on Indonesian Consumers. Journal of Industrial Engineering \& Management Research (JIEMAR), 2(3), 42-52. https://jiemar.org/ index.php/jiemar/article/view/144
Rachmawati, E., S. and Suroso, A. (2022), "A moderating role of halal brand awareness to purchase decision making", Journal of Islamic Marketing, Vol. 13 No. 2, pp. 542-563. https:// doi.org/10.1108/JIMA-05-2020-0145

Sekaran, Uma, \& Bougie, R. (2016). Research methods for business: A skill building approach. John Wiley \& Sons.

Simbolon, F. P. (2019). The Impact of Halal Label, Price, And Brand on the Purchase Decision of Bakso Wagyu in Kota Wisata Cibubur. The Winners, 20(2), 111. https://doi.org/10.21512/ tw.v20i2.5891

Wardani, K., \& Susanto, A. (2020). The Impact of Brand Image and Perceived Price on Imported Halal Skincare Purchase Decision: Study on Safi's Consumers in Central Java, Indonesia. International Journal of Science and Business, 4(10), 108-120. https://doi.org/ 10.5281/zenodo.4059333

Wibowo, S., \& Juhara, A. el. (2021). The Determinants of Halal Labeling and Brand Image Towards Purchase Intention and Purchasing Decision. Proceedings of the 4th International Conference on Sustainable Innovation 2020-Accounting and Management (ICoSIAMS 2020), 176(ICoSIAMS 2020), 1-3. https://doi.org/ 10.2991/aer.k.210121.001 